\title{
Lower platelet count early after the heart transplantation is asso- ciated with lower rates of cellular-mediated rejection within 24 months after heart transplantation
}

\author{
(1)Boško Skorić', \\ (DDora Fabijanović*, \\ (D) Marijan Pašalić1, \\ (iD)Ana Reschner \\ Planinc ${ }^{2}$, \\ (D) Hata Botonjić ${ }^{3}$, \\ (D)Jana Ljubas Maček', \\ (D)Maja Čikeš', \\ (DIvo Planinc', \\ (D) Jure Samardžić', \\ (D)Hrvoje Jurin', \\ (DDaniel Lovrić', \\ (D)Hrvoje Gašparović', \\ (D) Višnja Ivančan', \\ DDavor Miličić \\ 'University of Zagreb School \\ of Medicine, University \\ Hospital Centre Zagreb, \\ Zagreb, Croatia \\ 2Izola General Hospital, Izola \\ Slovenia \\ ${ }^{3}$ University of Zagreb School \\ of Medicine, Zagreb, Croatia
}

RECEIVED:

September 8, 2019

ACCEPTED:

September 16, 2019

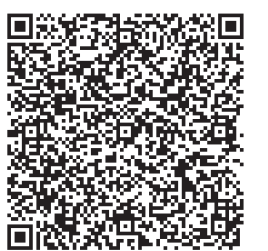

$\square$ Cardiologia Croatica 2019:14(9-10):224.
KEYWORDS: heart transplantation, platelet count, cellular-mediated rejection

CITATION: Cardiol Croat. 2019;14(9-10):224-5. | https://doi.org/10.15836/ccar2019.224

*ADDRESS FOR CORRESPONDENCE: Dora Fabijanović, Klinički bolnički centar Zagreb, Kišpatićeva 12, HR-10000 Zagreb, Croatia. / Phone: +385-98-9387-273 / E-mail: dora.fabijanovic@gmail.com

ORCID: Boško Skorić, https://orcid.org/0000-0001-5979-2346 • Dora Fabijanović, https://orcid.org/0000-0003-2633-3439 Marijan Pašalić, https://orcid.org/0000-0002-3197-2190 • Ana Reschner Planinc, https://orcid.org/0000-0002-6723-6822 Hata Botonjić, https://orcid.org/0000-0001-8314-1770 • Jana Ljubas Maček, https://orcid.org/0000-0001-7171-2206 Maja Čikeš, https://orcid.org/0000-0002-4772-5549 • Ivo Planinc, https://orcid.org/0000-0003-0561-6704 Jure Samardžić, https://orcid.org/0000-0002-9346-6402 • Hrvoje Jurin, https://orcid.org/0000-0002-2599-553X Daniel Lovrić, https://orcid.org/0000-0002-5052-6559 • Hrvoje Gašparović, https://orcid.org/0000-0002-2492-3702 Višnja Ivančan, https://orcid.org/0000-0002-7282-9753 • Davor Miličić, https://orcid.org/0000-0001-9101-1570

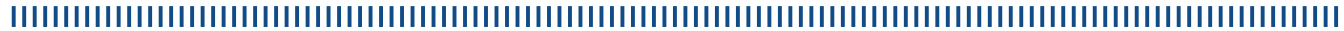
Background: Decrease in platelet count following the induction with polyclonal anti-thymocyte globulin (ATG) is deemed as an adverse event, while decrease in lymphocyte count represents a therapeutic goal $^{1}$. Still, the effect on platelets may represent an important part of ATG anti-rejection mechanisms. Patients and Methods: This was a retrospective single-center study of consecutive HTx (heart transplantation) patients (pts) from February 2010 to February 2018 in University Hospital Centre Zagreb. All pts received rATG (Thymoglobulin ${ }^{\circledR}$ ) $1.5 \mathrm{mg} / \mathrm{kg}$ daily during the first 5 days. Complete blood count with differential was assessed on days 0, 7 and 14 after HTx. The incidence of cellular-mediated rejection (ACR) was monitored for two years after HTx. ACR was classified according to ISHLT classification from 1990 and expressed as ACR of grade 1B or higher ( $\geq 1 \mathrm{~B})$.

TABLE 1. Univariate Analysis of Acute Cellular Rejection (ACR of grade $\geq 1 B$ ) in the first 2 years after heart transplantation.

\begin{tabular}{|c|c|c|c|}
\hline Variable & HR & $95 \% \mathrm{Cl}$ & $\mathrm{p}$ value \\
\hline Recipient age, years & 0.961 & $0.939-0.984$ & 0.001 \\
\hline \multicolumn{4}{|l|}{ Recipient gender } \\
\hline Male & 0.625 & $0.281-1.392$ & 0.25 \\
\hline Positive pre-transplant recipient CMV IgG & 0.319 & $0.133-0.766$ & 0.011 \\
\hline Donor/recipient CMV mismatch & 2.646 & $0.778-8.994$ & 0.119 \\
\hline Donor age, years & 0.971 & 0.943-1.001 & 0.059 \\
\hline \multicolumn{4}{|l|}{ Donor gender } \\
\hline Male & 1.594 & $0.643-3.949$ & 0.314 \\
\hline Pre-transplant mechanical circulatory support & 1.677 & $0.573-4.908$ & 0.345 \\
\hline Ischemia time, min & 1.001 & $0.995-1.007$ & 0.678 \\
\hline Absolute lymphocyte count on day $7, \times 10^{3} / \mu \mathrm{L}$ & 1.000 & 0.999-1.002 & 0.446 \\
\hline Absolute lymphocyte count on day $14, \times 10^{3} / \mu \mathrm{L}$ & 1.001 & $1.000-1.001$ & 0.074 \\
\hline Platelet count on day $7, \times 10^{3} / \mu \mathrm{L}$ & 1.007 & $1.002-1.013$ & 0.006 \\
\hline Platelet count on day $14, \times 10^{3} / \mu \mathrm{L}$ & 1.004 & $1.000-1.008$ & 0.074 \\
\hline Positive post-transplant CMV PCR & 0.501 & $0.118-2.127$ & 0.349 \\
\hline Calcineurin inhibitor, No. (\%) & 0.840 & $0.393-1.796$ & 0.653 \\
\hline Tacrolimus vs Cyclosporine & & & \\
\hline
\end{tabular}

$\mathrm{CMV}=$ Cytomegalovirus; $\mathrm{PCR}=$ polymerase chain reaction . 
Results: A total of 159 pts were transplanted. Median age was 55 years (IQR, 47-62 years), 76\% were male. A total of 27 pts (17\%) experienced ACR $\geq 1 B$ during 24 months. Pts with ACR of grade $\geq 1 B$ had higher platelet count on day 7 (145 vs $\left.104 \times 10^{3} / \mu \mathrm{L}, \mathrm{p}<0.001\right)$. They also had higher the absolute lymphocyte count (ALC) on the same day, but this did not reach statistical significance $\left(162 \mathrm{vs} 130 \mathrm{x} 10^{3} / \mu \mathrm{L}\right.$ $\mathrm{p}=0.19$ ) and there was no correlation between ALC and platelet counts on day 7 (Pearson's correlation coefficient was 0.064 , $p=0.459$ ). Conversely, more rejection was observed in pts with higher ALC on day 14 (326 vs $190 \mathrm{x} \mathrm{103/ \mu L,} \mathrm{p=0.035),} \mathrm{with} \mathrm{a} \mathrm{trend} \mathrm{towards} \mathrm{statisti-}$ cal significance in the relationship with higher platelet count (210 vs $\left.199 \times 10^{3} / \mu \mathrm{L}, \mathrm{P}=0.076\right)$. In the univariate analysis, higher platelet count on day 7, younger recipient age and negative pre-transplant Cytomegalovirus (CMV) IgG serology were found as predictors of the $\mathrm{ACR} \geq 1 \mathrm{~B}$ in the first 2 years after HTx (Table 1). In multivariable model, platelet count on day 7 and pre-transplant CMV serostatus were independent predictors of rejection. ROC analysis of the aforementioned model showed a satisfying AUC of 0.75.

Conclusion: Decrease in platelet count following the induction with rATG is strongly related to less graft rejection that is independent from the lymphodepleting effect. This indicates the importance of platelet involvement in anti-rejection mechanisms of ATG induction, and consequently a possible rationale for targeting platelets in future immunosuppressive regimens. 